\title{
PENCARIAN RUTE TERDEKAT SANGGAR TARI MENGGUNAKAN ALGORITMA FLOYD WHARSHALL DI WILAYAH SOLO DAN SEMARANG
}

\author{
Wibowo Wicaksono ${ }^{1}$, Suryaningtyas Rahayu ${ }^{2}$, Suprayogi ${ }^{3}$, \\ Edi Sugiarto ${ }^{4}$, Ardytha Luthfiarta ${ }^{5}$ \\ 1,2,3,4,5 Universitas Dian Nuswantoro \\ e-mail: ${ }^{1}$ wicak@dsn.dinus.ac.id, ${ }^{2} 111201508901 @$ mhs.dinus.ac.id, \\ ${ }^{3}$ suprayogi@dsn.dinus.ac.id, ${ }^{4}$ edi.sugiarto@dsn.dinus.ac.id, \\ 5 ardytha.luthfiarta@dsn.dinus.ac.id
}

\begin{abstract}
Abstrak
Sanggar tari merupakan sarana melakukan aktivitas berkesenitarian oleh sekelompok orang yang meliputi pelestarian, penelitian, dan kerjasama. Sanggar tari sangat diperlukan kehadirannya oleh masyarakat, seniman, dan pemerintah sebagai sarana untuk menumbuh kembangkan kesenian tari di Indonesia. Dengan upaya pemerintah dan seniman di Indonesia untuk melestarikan tari tradisional tersebut masyarakat terutama generasi muda lebih banyak berminat pada kesenian tari modern. Seiring dengan pesatnya perkembangan teknologi, pengaksesan informasi dapat dilakukan dimana dan kapan saja dengan media internet, baik menggunakan perangkat komputer, mobile device sehingga informasi yang dibutuhkan dapat diakses dengan cepat. Penelitian ini mengusulkan pembuatan aplikasi yang digunakan untuk mengakses informasi lokasi sanggar tari. Algoritma Floyd-Warshall digunakan untuk menentukan rute terdekat pada lokasi sanggar-sanggar tari.
\end{abstract}

Kata kunci: sanggar, tari, rute, Floyd warshall

\section{PENDAHULUAN}

Negara Indonesia memiliki kurang lebih 742 bahasa daerah dan 33 pakaian adat [14]. Dengan keragaman kebudayaan tersebut Indonesia memiliki keunggulan budaya dibandingkan Negara lain. Dengan beragamnya suku dan kebudayaan tersebut Indonesia memiliki ratusan jenis seni tari tradisional. Seni tari merupakan gerakan yang berirama yang dilakukan di suatu tempat dan waktu tertentu untuk mengekpresikan suatu perasaan dan menyampaikan pesan dari seseorang maupun kelompok.

Dalam rangka melestarikan, membina dan mengembangkan potensi seni tari tradisional di Indonesia, pemerintah dan seniman tari mengupayakan mendirikan lembaga pendidikan dan sanggar tari. Sanggar tari sengaja dibuat untuk mewadahi kreativitas seni warga masyarakat, khususnya dalam hal seni tari. Di sinilah tempat berkumpul mereka yang ingin mengenal lebih dekat tentang tarian tradisional khas daerah mereka. Sanggar tari juga tempat berkumpul para penari di daerah sekitar yang ingin memajukan dan melestarikan budaya daerah mereka [12].

Sanggar tari sebagai sarana melakukan aktivitas berkesenitarian oleh sekelompok orang yang meliputi pelestarian, penelitian, dan kerjasama. Sanggar tari sangat diperlukan kehadirannya oleh masyarakat, seniman, dan pemerintah sebagai sarana untuk menumbuh kembangkan kesenian tari di Indonesia. Dengan upaya pemerintah dan seniman di Indonesia untuk melestarikan tari tradisional tersebut masyarakat terutama generasi muda lebih banyak berminat pada kesenian tari modern. Hal tersebut disebabkan oleh perkembangan zaman dan teknologi dengan kemudahan akses informasi. Maka sebagai upaya mengimbangi perkembangan zaman. Diperlukan sarana untuk mengakses dan mempublikasi sanggar tari 
tradisional sehingga masyarakat terutama anak-anak mudah memiliki akses informasi lokasi sanggar-sanggar tari.

Seiring dengan pesatnya perkembangan teknologi, pengaksesan informasi dapat dilakukan dimana dan kapan saja dengan media internet, baik menggunakan perangkat komputer, mobile device sehingga informasi yang dibutuhkan dapat diakses dengan cepat. Terlebih lagi dengan menggunakan mobile device yang mudah dibawa-bawa, semakin memudahkan dalam mengakses informasi yang ada. Dalam upaya memudahkan pelestarian tari tradisional penelitian ini mengusulkan pembuatan aplikasi untuk mengakses informasi lokasi sanggar-sanggar tari terdekat. Penelitian ini didasari oleh penelitian sebelumnya dengan kasus pencarian lokasi terdekat salah satunya oleh Luh Joni yang mengusulkan pembuatan system informasi geografis untuk mencari lokasi pariwisata di bali. Penelitian tersebut menggunakan algoritma Dijkstra untuk memperhitungkan jarak dan rute terdekat pada lokasi pariwisata [2]. Selain itu terdapat penelitian oleh Ragil Saputra yang mengusulkan pembuatan system informasi geografis untuk mengakses lokasi pariwisata di kota Yogyakarta. Algoritma yang digunakan adalah Floyd-warshall. Berdasarkan hasil dari penelitian-penelitian tersebut system atau aplikasi yang diusulkan berhasil membantu masyarakat sebagai pengguna untuk mengakses informasi lokasi yang dibutuhkan [13].

Berdasarkan uraian diatas penelitian ini mengusulkan pembuatan aplikasi yang digunakan untuk mengakses informasi lokasi sanggar tari. Algoritma Floyd-Warshall digunakan untuk menentukan rute terdekat pada lokasi sanggar-sanggar tari. Algoritma Floyd-Warshall dan Dijkstra merupakan algoritma yang banyak digunakan dalam penelitian untuk pencarian rute terdekat. Namun algoritma Floyd-Warshall memiliki kelebihan dibanding Dijkstra yang menerapkan pemrograman dinamis dengan menjamin keberhasilan penemuan solusi optimum untuk kasus penentuan lintasan terpendek [9]. Dari latar belakang permasalahan maka ditentukan judul dari penelitian ini adalah "Pencarian Sanggar Tari Pada Kota Semarang Dan Solo Menggunakan Algoritma Floyd Wharshall”.

\section{METODE PENELITIAN}

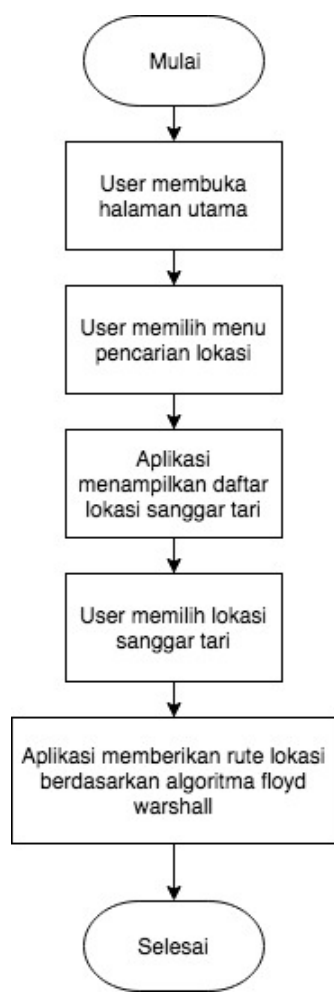

Gambar 1. Model yang Diusulkan 
Gambar diatas menjelaskan alur aplikasi yang diusulkan. Ketika user mulai membuka aplikasi akan ditampilkan menu utama. User memilih menu pencarian lokasi kemudian aplikasi menampilkan daftar lokasi-lokasi sanggar tari. User memilih lokasi yang dikehendaki, kemudian berdasarkan algoritma floyd warshall akan memberikan rekomendasi rute lokasi awal dengan lokasi yang dituju.

\section{HASIL DAN PEMBAHASAN}

Hasil dari penelitian membahas tahap-tahap pengembangan sistem sesuai dengan metode waterfall

\section{a. Tahap Analisa}

Tahap analisa menjelaskan proses berjalannya aplikasi serta bagaimana interaksinya dengan pengguna. Tahap awal dalam analisa menjelaskan kebutuhan fungsional pada aplikasi. Kebutuhan fungsional merupakan fitur atau fungsi yang harus ada pada aplikasi. Kebutuhan fungsional dibagi menjadi 2 yaitu untuk user dan admin.

User

1) Mengakses halaman utama aplikasi

2) Melihat persebaran sanggar tari pada peta

3) Melihat informasi sanggar tari

4) Memilih titik berangkat dan titik tujuan

5) Melihat rute antar titik

Admin

1) Login

2) Mengelola data sanggar tari

3) Mengelola data rute

\section{b. Tahap Desain}

Model perancangan yang digunakan pada penelitian ini adalah Unified Modeling Language (UML) yang meliputi use case diagram, sequence diagram, dan class diagram, activity diagram.

1) Use Case Diagram

Dalam use case diagram memperlihatkan hubungan antara actor dan use case. Actor merepresentasikan seorang user yang berinteraksi dengan sistem. Sedangkan use case merupakan urutan dari kegiatan yang menggambarkan interaksi antara user dan sistem. Fungsionalitas sistem didefinisikan kedalam use case dari sudut eksternal yang berguna untuk uji kelayakan sistem.

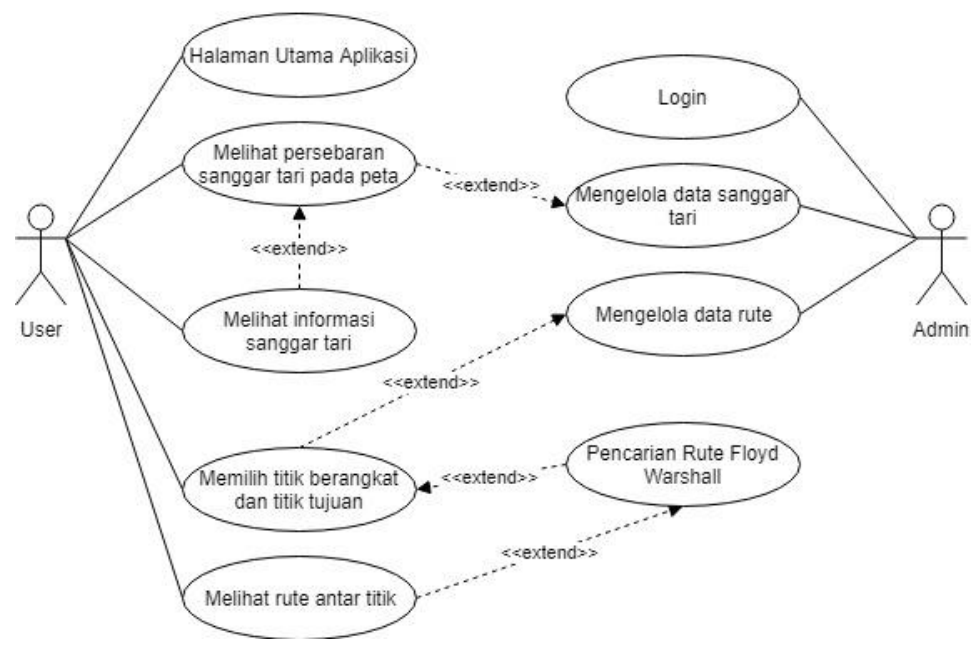

Gambar 2. Usecase Diagram 
Usecase diatas menggambarkan interaksi antara pengguna yang terdiri dari admin dan user dengan system. Usecase dibuat berdasarkan kebutuhan fungsional yang telah dideskripsikan pada tahap analisa.

Tabel 1. Deskripsi Usecase

\begin{tabular}{|l|l|l|}
\hline Aktor & \multicolumn{1}{|c|}{ Nama Usecase } & \multicolumn{1}{|c|}{ Deskripsi } \\
\hline Admin & Login & $\begin{array}{l}\text { Untuk masuk sebagai administrator pengguna dapat } \\
\text { login dengan memasukan username dan password }\end{array}$ \\
\hline Admin & $\begin{array}{l}\text { Mengelola data } \\
\text { sanggar tari }\end{array}$ & $\begin{array}{l}\text { Administrator dapat mengelola data sanggar tari dengan } \\
\text { memasukan data-data penting seperti nama, telepon, } \\
\text { deskripsi, alamat dan lokasi. Pengelolaan meliputi input, } \\
\text { edit dan hapus. }\end{array}$ \\
\hline Admin & Mengelola data rute & $\begin{array}{l}\text { Administrator dapat mengelola data rute dengan } \\
\text { memasukan titik start dan titik end beserta jarak antar } \\
\text { titik tersebut. Pengelolaan meliputi input, edit dan hapus. }\end{array}$ \\
\hline User & $\begin{array}{l}\text { Mengakses halaman } \\
\text { utama aplikasi }\end{array}$ & $\begin{array}{l}\text { Halaman utama merupakan halaman awal yang } \\
\text { ditampilkan ketika user mengakses aplikasi. }\end{array}$ \\
\hline User & $\begin{array}{l}\text { Melihat persebaran } \\
\text { sanggar tari pada } \\
\text { peta }\end{array}$ & $\begin{array}{l}\text { Persebaran sanggar tari merupakan halaman yang } \\
\text { digunakan untuk menampilkan lokasi-lokasi sanggar tari } \\
\text { yang tersebar di kota semarang pada peta }\end{array}$ \\
\hline User & $\begin{array}{l}\text { Melihat informasi } \\
\text { sanggar tari }\end{array}$ & $\begin{array}{l}\text { Pada halaman persebaran user dapat melihat informasi } \\
\text { terkait dengan sanggar tari yang dipilih }\end{array}$ \\
\hline User & $\begin{array}{l}\text { Memilih titik } \\
\text { berangkat dan titik } \\
\text { tujuan }\end{array}$ & $\begin{array}{l}\text { Pada halaman pencarian rute user memasukan titik } \\
\text { berangkat dan titik tujuan sanggar tari. }\end{array}$ \\
\hline Sistem & $\begin{array}{l}\text { Pencarian Rute } \\
\text { Floyd-Warshall }\end{array}$ & $\begin{array}{l}\text { Pada usecase ini system bekerja dengan mencari rute } \\
\text { berdasarkan input titik berangkat dan titik tujuan yang } \\
\text { dipilih oleh user. Proses pencarian rute pada setiap titik } \\
\text { menggunakan algoritma Floyd-warshall }\end{array}$ \\
\hline titik & $\begin{array}{l}\text { Pada halaman ini aplikasi menampilkan hasil pencarian } \\
\text { rute terdekat antar titik berangkat dan tujuan. }\end{array}$ \\
\hline
\end{tabular}

2) Sequence Diagram

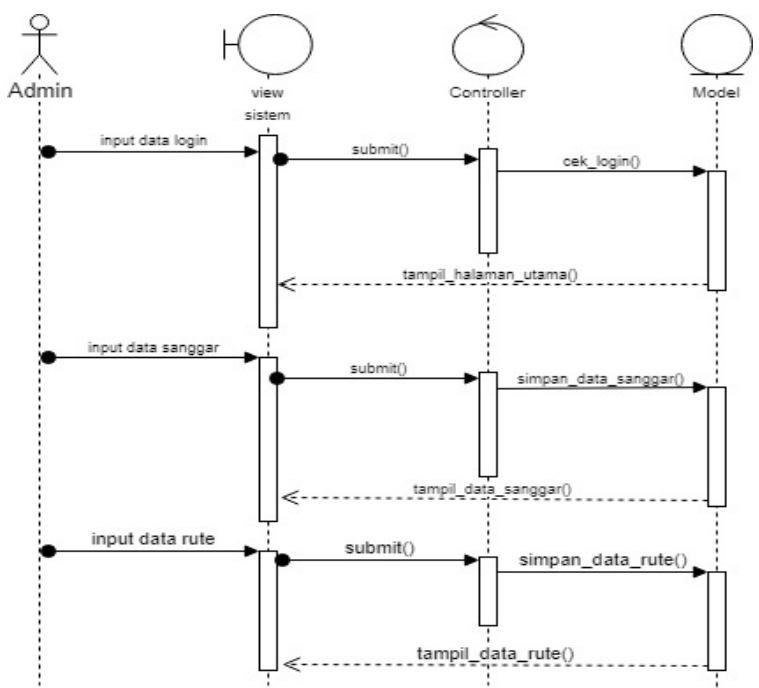

Gambar 3. Sequence Diagram 
Pada sequence diagram admin dimulai dari input data login. Kemudian form input di submit dan memanggil fungsi cek_login(). Setelah berhasil admin akan diarahkan pada halaman utama. Kemudian admin dapat menginput data sanggar dengan proses submit form dan system akan menyimpan data sanggar ke database. Admin dapat menginput data rute dengan proses submit form dan system akan menyimpan data rute ke database.

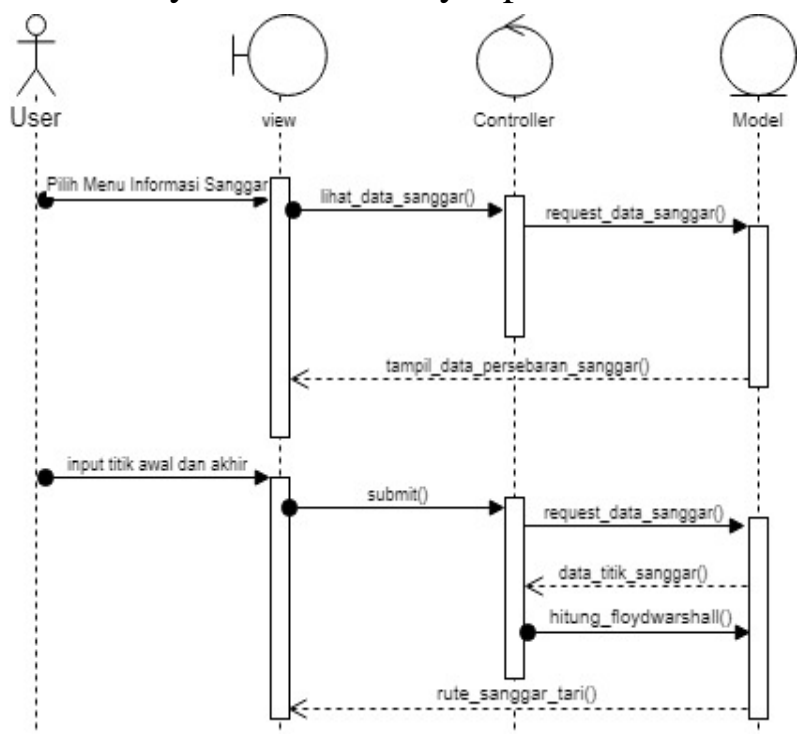

Gambar 4. Sequence Diagram User

Pada sequence diagram user proses mengakses informasi sanggar dimulai ketika user memilih menu informasi sanggar kemudian aplikasi akan memanggil fungsi request_data_sanggar() yang menampilkan data persebaran lokasi pada peta beserta informasi detail setiap sanggar tari. Proses pencarian rute dimulai ketika user menginput data berangkat dan tujuan kemudian form submit. Aplikasi akan melakukan proses perhitungan Floyd Warshall dan menampilkan rute terdekat berdasarkan hasil perhitungan

3) Activity Diagram

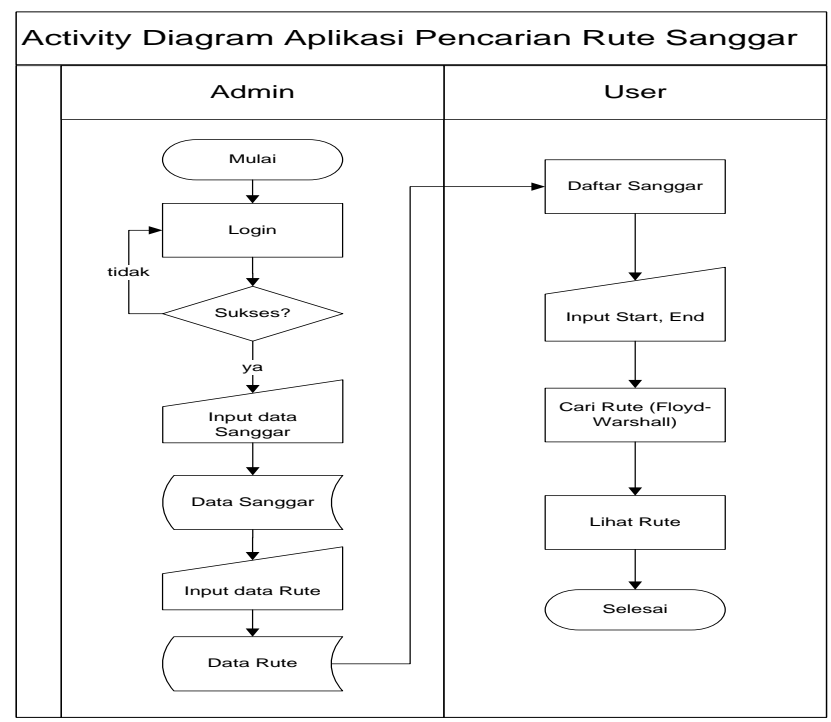

Gambar 5. Activity Diagram Sistem Peringkas berita

Activity Diagram diatas menggambarkan worlflow (aliran kerja) atau aktivitas dari sebuah sistem atau proses bisnis pada aplikasi pencarian rute sanggar tari. Activity diagram diatas menjelaskan urutan proses yang dilakukan oleh actor admin sampai dengan proses yang dilakukan oleh user. 


\section{c. Tahap Implementasi}

Berikut ini menjelaskan tahapan-tahapan implementasi sistem penjualan yang diimplementasikan kedalam website. Sebelum diimplemenatasi tahap pengkodean dilakukan untuk menerjemahkan desain ke dalam bentuk intruksi-intruksi yang dapat dijalankan oleh mesin. Penulisan coding menggunakan bahasa pemrograman PHP(Hypertext Preprocessor).

Hasil dari implementasi system menjelaskan tahap-tahap alur system yang digunakan pengguna mulai dari login, input berita hingga output hasil ringkasan.

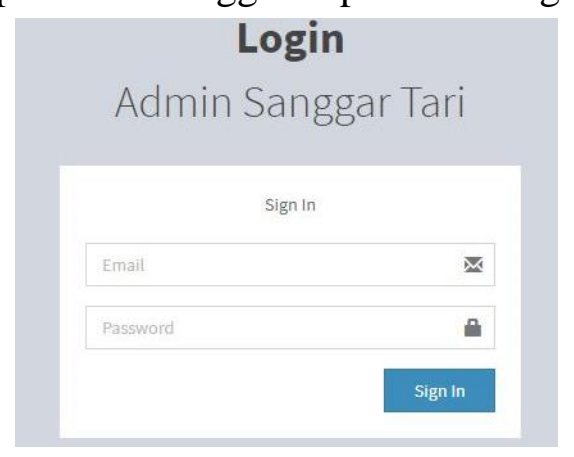

Gambar 6. login system

Tampilan login system digunakan untuk administrator laporbup dan administrator dinas-dinas yang terdaftar. Pengguna sebagai administrator dapat melakukan login kedalam system dengan memasukan username dan password.

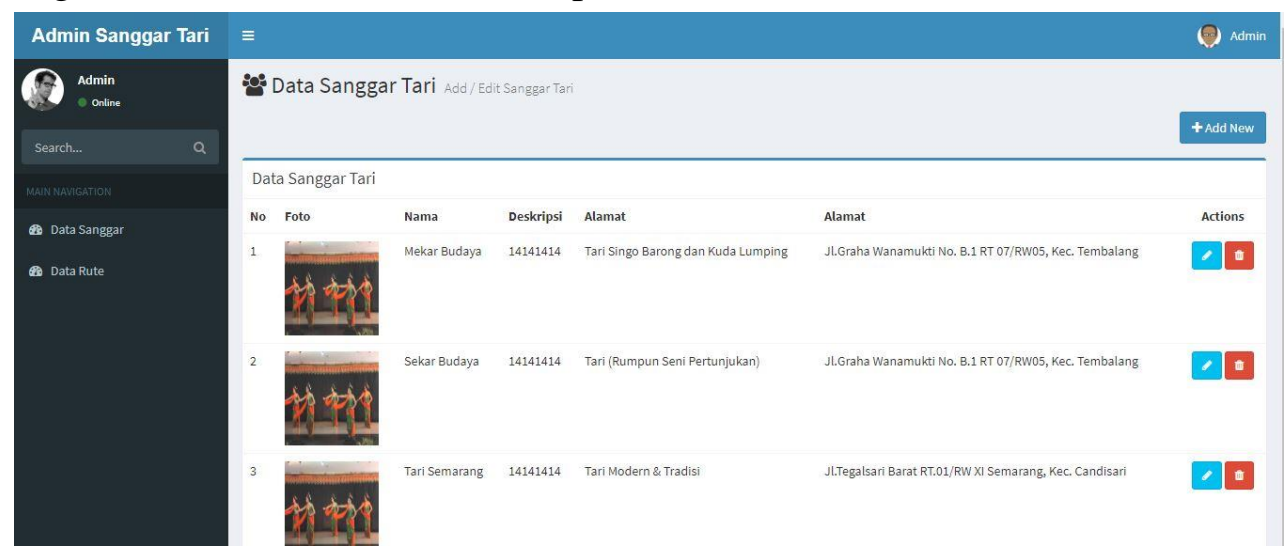

Gambar 7. Halaman Sanggar Tari

Gambar diatas menunjukan tampilan awal ketika login berhasil. Halaman yang ditunjukan merupakan halaman data sanggar tari yang ditampilkan dalam bentuk tabel. Admin dapat mengelola data meliputi menambah, menghapus dan mengedit data sanggar.

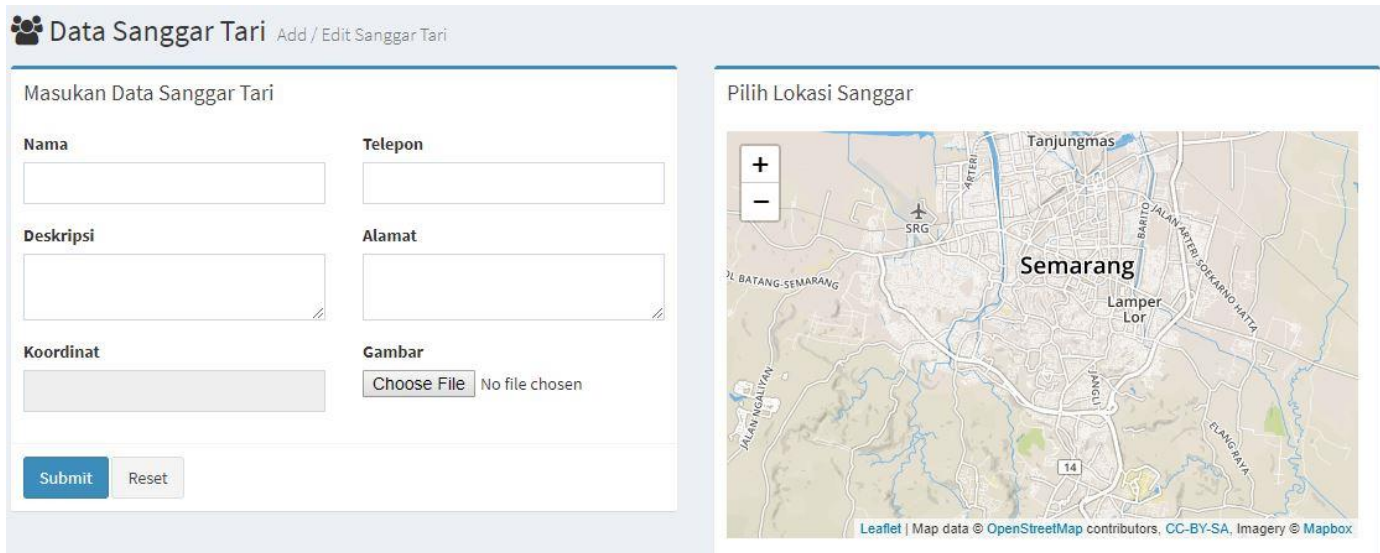

Gambar 8. Input Sanggar 
Gambar diatas ditunjukan form input data sanggar tari. Terdapat beberapa komponen input data terkait sanggar yaitu nama, telepon, deskripsi, alamat, koordinat dan gambar. Koordinat dipilih dengan mengklik peta sesuai lokasi sanggar. Gambar diinput dengan memilih file yang terdapat pada computer admin.

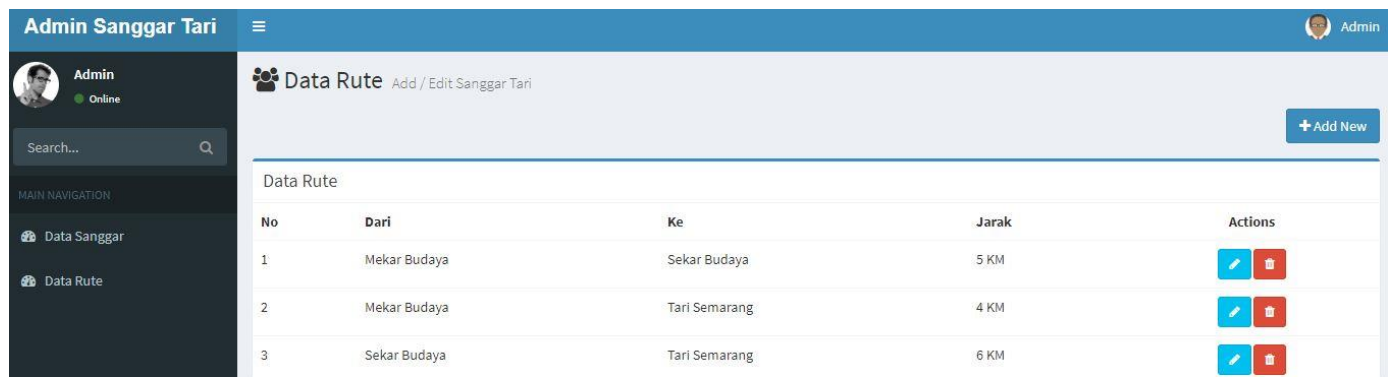

Gambar 9. Halaman Rute

Gambar diatas menunjukan data rute yang telah dibuat dan tersimpan di database. Data rute ditampilkan dalam bentuk tabel dengan informasi titik awal dan titik akhir beserta jaraknya. Admin dapat mengelola data meliputi tambah, edit dan hapus.

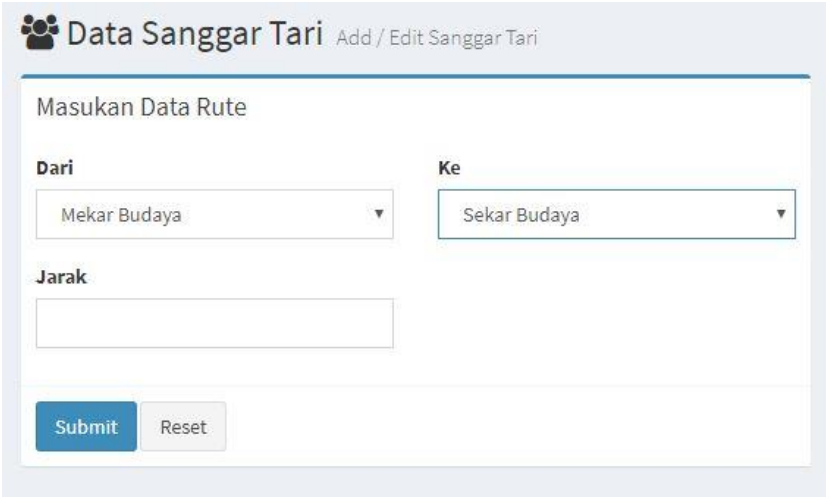

Gambar 10. Halaman Input Rute

Gambar diatas menunjukan tampilan form input rute. Form input terdiri dari input titik awal, titik akhir dan jarak antar titik tersebut.

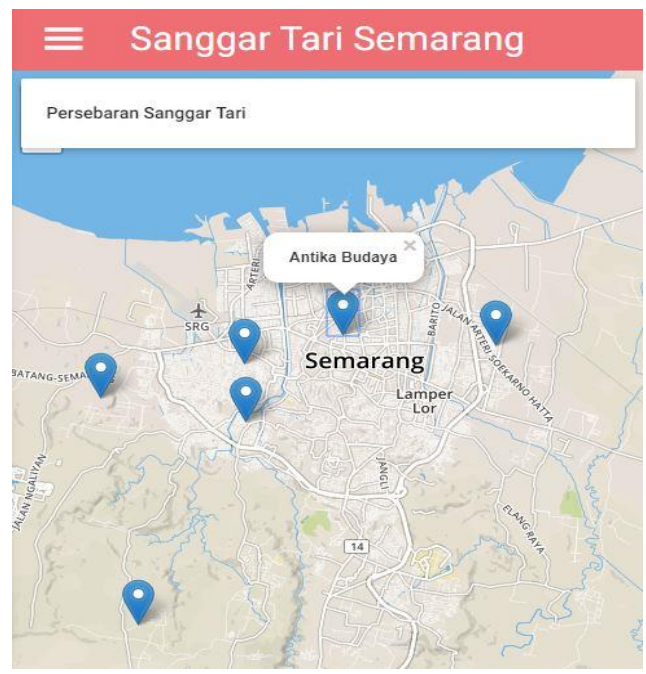

\section{Gambar 11. Halaman Persebaran Sanggar Tari}

Pada gambar diatas ditunjukan halaman persebaran sanggar tari. Persebaran lokasi sanggar tari ditampilkan dalam bentuk marker-marker pada peta. Ketika marker diklik maka akan menampilkan informasi terkait dengan sanggar yang dipilih. 


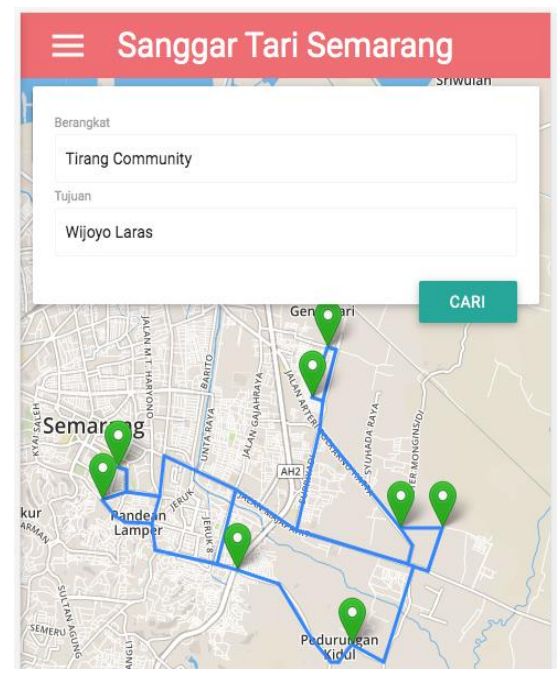

Gambar 12. Halaman Cari Rute

Gambar diatas menunjukan tampilan form input untuk mencari rute. Pada pencarian rute tahap awal yang dilakukan oleh user adalah memilih titik berangkat dan titik tujuan.

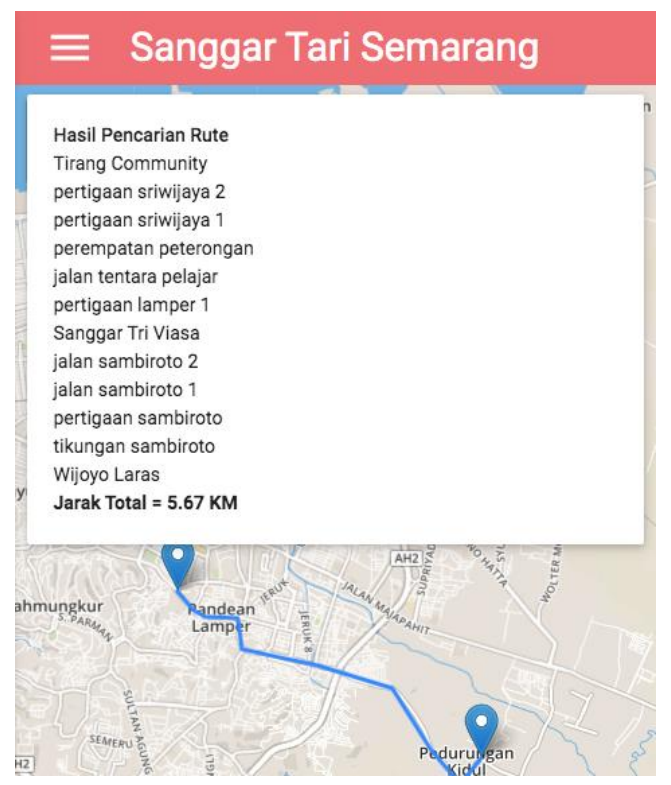

Gambar 13. Halaman Hasil Pencarian Rute

Gambar diatas menunjukan tampilan hasil rute yang diproses menggunakan algoritma Floyd warshall. Rute ditampilkan antar titik yang berhubungan dari titik berangkat hingga titik tujuan

\section{d. Tahap Pengujian}

Pengujian Floyd warshall dilakukan untuk mengetahui proses pencarian jarak rute terpendek pada titik sanggar tari. Pengujian dilakukan menggunakan data sampel yang ditampilkan pada tabel dibawah:

Tabel 2. Data Sampel Pengujian

\begin{tabular}{|c|l|l|l|}
\hline No & Nama Kelompok & \multicolumn{1}{|c|}{ Jenis Kelompok } & \multicolumn{1}{|c|}{ Alamat Sekertariat } \\
\hline 1 & Wijoyo Laras & $\begin{array}{l}\text { Pedalangan dan } \\
\text { Drama Tari }\end{array}$ & $\begin{array}{l}\text { JL.Karanganyar Raya NO.7 Ngasem } \\
\text { Semarang, Kec. Banyumanik }\end{array}$ \\
\hline 2 & Tirang Community & $\begin{array}{l}\text { Seni Tari, Seni Teater } \\
\text { dan Seni Musik }\end{array}$ & $\begin{array}{l}\text { J1. Sriwijaya no. 29 Kel. Tegal Sari, } \\
\text { Kec. Candisari }\end{array}$ \\
\hline
\end{tabular}




\begin{tabular}{|c|c|c|c|}
\hline 3 & Sanggar Tri Viasa & Tari & $\begin{array}{l}\text { JL. Menoreh Utara IV/9 Semarang, } \\
\text { Kec. Gajah Mungkur }\end{array}$ \\
\hline 4 & Pradapa Budaya & Sendratasik & $\begin{array}{l}\text { J1. Karang Kimpul Rt03/Rw01 } \\
\text { Tambakrejo , Kec. Gayamsari }\end{array}$ \\
\hline 5 & $\begin{array}{l}\text { Sanggar Tari Yasa } \\
\text { Budaya Aryamukti }\end{array}$ & Seni Tari & Bangetayu Kulon rt.3 rw.2, Kec.Genuk \\
\hline 6 & $\begin{array}{l}\text { Sanggar tari Sekar } \\
\text { Kemuning }\end{array}$ & Seni Tari & $\begin{array}{l}\text { JL.Randutari 1/302 Semarang, Kec. } \\
\text { Gunung Pati }\end{array}$ \\
\hline 7 & Mardayu & $\begin{array}{l}\text { Seni Tari, Karawitan, } \\
\text { Tembang Jawa, } \\
\text { Pedhalangan }\end{array}$ & $\begin{array}{l}\text { Jl. Wahyu Temurun XIII RT 10/RW } 21 \\
\text { Kel. Tlogosari Kulon, Kec. Pedurungan, } \\
\text { Semarang }\end{array}$ \\
\hline 8 & $\begin{array}{l}\text { Sanggar Puspo } \\
\text { Nugroho }\end{array}$ & Tari & $\begin{array}{l}\text { Jl. Abdul rahman Saleh No. } 1 \text { Semarang } \\
\text { Barat }\end{array}$ \\
\hline
\end{tabular}

Tabel 3. Titik Pengujian Sanggar Tari

\begin{tabular}{|c|l|c|}
\hline No & Nama Kelompok & Kode \\
\hline 1 & Mardayu & S1 \\
\hline 2 & Sanggar Puspo Nugroho & S2 \\
\hline 3 & Sanggar tari Sekar Kemuning & S3 \\
\hline 4 & Sanggar Tari Yasa Budaya Aryamukti & S4 \\
\hline 5 & Wijoyo Laras & S5 \\
\hline 6 & Sanggar Tri Viasa & S6 \\
\hline 7 & Tirang Community & S7 \\
\hline 8 & Pradapa Budaya & S8 \\
\hline
\end{tabular}

Input dari algoritma Floyd warhsall merupakan titik-titik yang terhubung dan akan membentuk menjadi kesatuan jalur. Titik titik dibentuk dengan jarak yang ditampilkan pada tabel dibawah.

Tabel 4. Jarak Rute Sanggar Tari

\begin{tabular}{|c|c|r|}
\hline Start & End & Jarak \\
\hline S1 & S2 & 0.8 \\
\hline S1 & S3 & 3.59 \\
\hline S2 & S3 & 2.77 \\
\hline S2 & S6 & 5.2 \\
\hline S2 & S7 & 6.62 \\
\hline S2 & S8 & 6.67 \\
\hline S3 & S4 & 0.74 \\
\hline S3 & S5 & 3.04 \\
\hline S4 & S5 & 3.27 \\
\hline S5 & S6 & 2.8 \\
\hline S6 & S7 & 2.8 \\
\hline S6 & S8 & 3.42 \\
\hline S7 & S8 & 0.96 \\
\hline
\end{tabular}


Berdasarkan titik titik jarak diatas menghasilkan matriks jarak yang ditampilkan pada tabel dibawah:

Tabel 5. Matriks Jarak Antar Titik

\begin{tabular}{|l|c|c|c|c|c|c|c|c|}
\hline & S1 & S2 & S3 & S4 & S5 & S6 & S7 & S8 \\
\hline S1 & 0 & 0.8 & 3.59 & $\infty$ & $\infty$ & $\infty$ & $\infty$ & $\infty$ \\
\hline S2 & 0.8 & 0 & 2.77 & $\infty$ & $\infty$ & 5.2 & 6.62 & 6.67 \\
\hline S3 & 3.59 & 2.77 & 0 & 0.74 & 3.04 & $\infty$ & $\infty$ & $\infty$ \\
\hline S4 & $\infty$ & $\infty$ & 0.74 & 0 & 3.27 & $\infty$ & $\infty$ & $\infty$ \\
\hline S5 & $\infty$ & $\infty$ & 3.04 & 3.27 & 0 & 2.8 & $\infty$ & $\infty$ \\
\hline S6 & $\infty$ & $\infty$ & $\infty$ & $\infty$ & 2.8 & 0 & 2.8 & $\infty$ \\
\hline S7 & $\infty$ & $\infty$ & $\infty$ & $\infty$ & $\infty$ & 2.8 & 0 & 0.96 \\
\hline S8 & $\infty$ & $\infty$ & $\infty$ & $\infty$ & $\infty$ & $\infty$ & 0.96 & 0 \\
\hline
\end{tabular}

Berdasarkan matriks jarak pada tabel 5 dibuat rute yang ditunjukan pada gambar diatas. Pengujian dilakukan dengan sampel titik dibawah

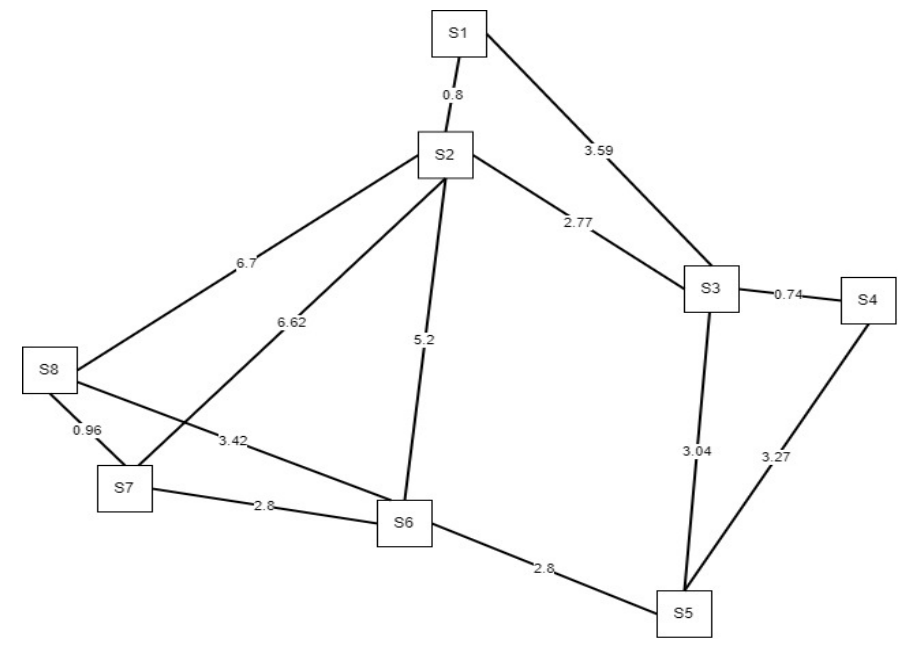

Gambar 14. Rute Keseluruhan Titik

Gambar 14 ditunjukan node node yang terhubung menghasilkan rute keseluruhan. Node node tersebut dibuat untuk memudahkan dalam representasi pembuatan perhitungan jarak menggunakan algoritma Floyd warshall.

Setelah dibuat node berdasarkan matriks jarak pada tabel 6 dilakukan pengujian menggunakan sampel titik yang terdiri dari titik berangkat dan titik tujuan. Pengujian dilakukan sebagai berikut

a) Titik $\mathrm{S} 1-\mathrm{S} 4$

Tabel 6. Kemungkinan Rute Titik S1-S4

\begin{tabular}{|l|l|l|c|}
\hline \multicolumn{1}{|c|}{ No } & \multicolumn{1}{|c|}{ Rute } & \multicolumn{1}{|c|}{ Jarak } & Total \\
\hline 1 & S1, S3, S4 & $3.54+0.74$ & 4.28 \\
\hline 2 & S1, S2, S3, S4 & $0.8+2.77+0.74$ & 4.31 \\
\hline 3 & S1, S2, S8, S7, S6, S5, S3, S4 & $0.8+6.7+0.96+2.8+2.8+3.04+0.74$ & 17.84 \\
\hline 4 & S1, S2, S8, S6, S5, S3, S4 & $0.8+6.7+3.42+2.8+3.04+0.74$ & 17.5 \\
\hline 5 & S1, S2 S8, S7, S6, S5, S4 & $0.8+6.7+3.42+2.8+3.27$ & 16.99 \\
\hline 6 & S1, S2, S7, S6, S5, S3, S4 & $0.8+6.62+2.8+3.04+0.74$ & 14 \\
\hline
\end{tabular}




\begin{tabular}{|l|l|l|l|}
\hline 7 & S1, S2, S6, S5, S3, S4 & $0.8+5.2+2.8+3.04+0.74$ & 12.54 \\
\hline 8 & S1, S2, S6, S5, S4 & $0.8+5.2+2.8+3.27$ & 12.07 \\
\hline
\end{tabular}

Pada tabel diatas terdapat 8 kemungkinan rute dengan jarak total masing-masing rute. Rute yang diambil adalah S1, S3, S4 dengan jarak 4.28

b) Titik S1 - S5

Tabel 7. Kemungkinan Rute Titik S1-S5

\begin{tabular}{|l|l|l|c|}
\hline No & \multicolumn{1}{|c|}{ Rute } & \multicolumn{1}{c|}{ Jarak } & Total \\
\hline 1 & S1, S2, S3, S5 & $0.8+2.77+3.04$ & 6.61 \\
\hline 2 & S1, S2, S3, S4, S5 & $0.8+2.77+0.74+3.27$ & 7.58 \\
\hline 3 & S1, S3, S4, S5 & $3.59+0.74+3.27$ & 7.6 \\
\hline 4 & S1, S3, S5 & $3.59+3.04$ & 6.63 \\
\hline 5 & S1, S2, S8, S7, S6, S5 & $0.8+6.7+0.96+2.8+2.8$ & 14.06 \\
\hline 6 & S1, S2, S7, S6, S5 & $0.8+6.2+2.8+2.8$ & 12.6 \\
\hline 7 & S1, S2, S6, S5 & $0.8+5.2+2.8$ & 8.8 \\
\hline
\end{tabular}

Pada tabel diatas terdapat 7 kemungkinan rute dengan jarak total masing-masing rute. Rute yang diambil adalah S1, S3, S5 dengan jarak 6.63

c) Titik S1 - S8

Tabel 8. Kemungkinan Rute Titik S1-S8

\begin{tabular}{|l|l|l|c|}
\hline No & \multicolumn{1}{|c|}{ Rute } & \multicolumn{1}{|c|}{ Jarak } & Total \\
\hline 1 & S1, S2, S6, S7, S8 & $0.8+5.2+2.8+0.96$ & 9.76 \\
\hline 2 & S1, S2, S6, S8 & $0.8+5.2+3.42$ & 9.42 \\
\hline 3 & S1, S2, S7, S8 & $0.8+6.62+0.96$ & 8.38 \\
\hline 4 & S1, S2, S8 & $0.8+6.7$ & 7.5 \\
\hline 5 & S1, S2, S3, S4, S5, S6, S7, S8 & $0.8+2.77+0.74+3.27+2.8+2.8+0.96$ & 14.16 \\
\hline 6 & S1, S2 ,S3, S5, S6, S7, S8 & $0.8+2.77+3.04+2.8+2.8+0.96$ & 14.16 \\
\hline 7 & S1, S3, S4, S5, S6, S7, S8 & $3.59+0.74+3.27+2.8+2.8+0.96$ & 14.16 \\
\hline 8 & S1, S3, S5, S6, S7, S8 & $3.59+3.04+2.8+2.8+0.96$ & 14.16 \\
\hline
\end{tabular}

Pada tabel diatas terdapat 8 kemungkinan rute dengan jarak total masing-masing rute. Rute yang diambil adalah S1, S2, S8 dengan jarak 7.5

Berdasarkan sampel pengujian tersebut maka hasil dirangkum pada tabel 9

Tabel 9. Hasil Pengujian Algoritma Floyd Warshall

\begin{tabular}{|l|c|c|c|}
\hline No & Titik & Rute & Jarak Total \\
\hline 1 & S1 - S4 & S1, S3, S4 & 4.28 \\
\hline 2 & S1 - S5 & S1, S3, S5 & 6.63 \\
\hline 3 & S1 - S8 & S1, S2, S8 & 7.5 \\
\hline
\end{tabular}

Metode pengujian yang di gunakan untuk menguji aplikasi adalah pengujian blackbox. Pengujian blackbox dilakukan untuk memastikan tanggapan/respons atas suatu event atau masukan akan menjelankan proses yang tepat dan menghasilkan keluaran/output sesuai dengan rancangan yang telah dibuat. Uji ini dilakukan pada menu utama dengan hasil sebagai berikut: 
Tabel 10. Pengujian Blackbox

\begin{tabular}{|l|l|c|}
\hline \multicolumn{1}{|c|}{ Input / Event } & \multicolumn{1}{|c|}{ Output } & Hasil \\
\hline Klik tombol Login Admin & $\begin{array}{l}\text { Menampilkan Login Sukses dan } \\
\text { menampilkan Form Menu Utama }\end{array}$ & Sesuai / OK \\
\hline $\begin{array}{l}\text { Klik tombol Masuk setelah } \\
\text { Login }\end{array}$ & Menampilkan Halaman Utama Admin & Sesuai / OK \\
\hline $\begin{array}{l}\text { Klik tombol menu Data } \\
\text { Sanggar Tari }\end{array}$ & $\begin{array}{l}\text { Menampilkan Halaman untuk data Sanggar } \\
\text { Tari }\end{array}$ & Sesuai / OK \\
\hline $\begin{array}{l}\text { Klik tombol tambah pada } \\
\text { menu Data Sanggar Tari }\end{array}$ & Menyimpan hasil input data sanggar tari & Sesuai / OK \\
\hline Klik tombol menu Data Rute & Menampilkan Halaman untuk data rute & Sesuai / OK \\
\hline $\begin{array}{l}\text { Klik tombol tambah pada } \\
\text { menu Data Rute }\end{array}$ & Menyimpan hasil input data rute & Sesuai / OK \\
\hline User membuka aplikasi & Tampilan awal aplikasi & Sesuai / OK \\
\hline $\begin{array}{l}\text { Klik tombol menu persebaran } \\
\text { sanggar tari }\end{array}$ & $\begin{array}{l}\text { Menampilkan halaman persebaran sanggar } \\
\text { tari }\end{array}$ & Sesuai / OK \\
\hline Klik menu rute & $\begin{array}{l}\text { Menampilkan form input titik berangkat dan } \\
\text { tujuan }\end{array}$ & Sesuai / OK \\
\hline $\begin{array}{l}\text { Mengisi form input titik } \\
\text { berangkat dan tujuan }\end{array}$ & $\begin{array}{l}\text { Mengaktifkan tombol cari untuk memulai } \\
\text { pencarian rute }\end{array}$ & Sesuai / OK \\
\hline $\begin{array}{l}\text { Klik tombol cari setelah } \\
\text { mengisi form input pencarian }\end{array}$ & $\begin{array}{l}\text { Melakukan pencarian rute yang dapat di } \\
\text { gunakan lalu menampilkan titik titik rute } \\
\text { beserta jarak total }\end{array}$ & Sesuai / OK \\
\hline Klik tombol bantuan & Menampilkan halaman bantuan untuk user & Sesuai / OK \\
\hline $\begin{array}{l}\text { Klik tombol Tentang aplikasi } \\
\text { Penampilkan halaman tentang aplikasi }\end{array}$ & Sesuai / OK \\
\hline
\end{tabular}

\section{KESIMPULAN}

Berdasarkan hasil implementasi dan pengujian tentang penelitian Pencarian Sanggar Tari Pada Kota Semarang Dan Solo Menggunakan Algoritma Floyd Wharshall yang dilakukan, maka diambil kesimpulan adalah pencarian akses informasi lokasi sanggar tari terdekat dengan algoritma Floyd Warshall berbasis aplikasi mobile berhasil dibuat menggunakan Bahasa pemrograman PHP dan MySQL. Berdasarkan pengujian algoritma algoritma Floyd Warshall telah berhasil digunakan untuk mencari rute sanggar tari terdekat berdasarkan alternative beberapa rute. Pengujian secara blackbox juga telah dilakukan pada aplikasi berbasis web mobile dengan hasil sesuai dengan fungsi dan tidak terdapat error.

\section{SARAN}

Berdasarkan kesimpulan dan analisis laporan, saran dari peneliti untuk penelitian lebih lanjut yaitu Penelitian lebih lanjut dapat dikembangkan untuk memperluas area pencarian dalam hal ini tidak hanya wilayah Semarang namun juga Jawa Tengah. Fitur yang dapat dikembangkan untuk penelitian selanjutnya adalah penggunaan Paps tampil lebih dari satu lokasi sanggar sehingga pengguna aplikasi dapat mengunjungi lokasi dengan opsi beberapa titik sanggar secara langsung. Dapat dikembangkan menggunakan algoritma lain seperti Dijkstra, A*, Haversine dan pencarian lokasi lainnya. 


\section{DAFTAR PUSTAKA}

[1] Amiral, M., 2010. Aplikasi Pengingat Shalat dan Arah Kiblat Berdasarkan Global Positioning System (GPS) Berbasis Android 1.6. Tugas Akhir Program Studi Teknik Informatika.

[2] Dewi, L. J. E., 2010. PENCARIAN RUTE TERPENDEK TEMPAT WISATA DI BALI DENGAN MENGGUNAKAN ALGORITMA DIJKSTRA. Seminar Nasional Aplikasi Teknologi Informasi.

[3] Group, P., 2014. PHP: Hypertext preprocessor. [Online] Available at: http://php.net/

[4] HM, J., 2006. Analisis dan Desain Sistem Informasi. Yogyakarta: ANDI.

[5] Hofmann, W., Bernhard, H. L. \& Collins, J., 2012. Global positioning system: theory and practice. s.1.:Springer Science \& Business Media.

[6] Informasi, B. K., 2013. Pengguna Internet di Indonesia. [Online] Available https://kominfo.go.id/index.php/content/detail/3415/Kominfo+\%3A+Pengguna+Internet +di+Indonesia+63+Juta+Orang/0/berita_satker

[7] Irwansyah, E., 2013. Sistem informasi geografis: prinsip dasar dan pengembangan aplikasi. Yogyakarta: DigiBook.

[8] Murya, Y., Jakarta. Pemrograman Android Black Box. Dalam: s.1.:Jasakom.

[9] Novandi, R. A. D., 2013. Perbandingan Algoritma Dijkstra dan Algoritma FloydWarshall dalam Penentuan Lintasan Terpendek (Single Pair Shortest Path). Strategi Algoritmik.

[10] Pressman, R. S., 2015. Software Engineering: A Practioner's Approach, Eighth Edition. New York: s.n.

[11] Safaat, N., 2012. Android (Pemograman Aplikasi Mobile Smartphone dan Tablet PC Berbasis Android). Bandung: Informatika.

[12] Sanara, A., 2010. Metode Pengenalan Tari Tradisional Jawa Berbasis Multimedia pada Sanggar Tari Ndalem Pujokusuman Yogyakarta. Skripsi.

[13] Saputra, R., 2011. SISTEM INFORMASI GEOGRAFIS PENCARIAN RUTE OPTIMUM OBYEK WISATA KOTA YOGYAKARTA DENGAN ALGORITMA FLOYD-WARSHALL.

[14] Tondo, H., 2009. Kepunahan Bahasa-Bahasa Daerah: Faktor Penyebab dan Implikasi Etnolinguistis. Dalam: Jurnal Masyarakat dan Budaya. s.1.:s.n. 